\title{
Az esés epidemiológiája, esésmegelőző stratégiát segítő és gátló tényezők a Csongrád megyei idősotthonokban
}

10.14232/actasana.2020.2.3-11

\begin{abstract}
ABSZTRAKT Az idősotthonokban nagy kihívást jelent az időskorúak esésének megelőzése. Külföldi szakirodalmakban az esés gyakoriságát 50-70\%-ra becsülik. Kutatásunk célja meghatározni az idősotthonokban az egészségügyi végzettségü ápolók számát, akik aktívan vesznek részt az esésmegelözési stratégia kialakításában és végrehajtásában, továbbá feltérképezni a stratégiát segítő és gátló tényezőket. Kvalitatív vizsgálatunk során mélyinterjút folytattunk, félig strukturált kérdések mentén. A minta kiválasztására szakértői mintavételt alkalmaztunk. A vizsgálatban összesen 21 intézmény vett részt és az interjúalanyok a Csongrád megyei minta 26,5\%át jelentették. A vizsgált idősotthonokban átlagosan 25,35 idős lakó jut egy egészségügyi végzettségü személyre. Az esések gyakorisága átlagosan 30\%ra tehető az interjúk alapján, és $10 \%$-ra az esések következtében kialakult szövődmények. Az esés kockázatának megítélésére objektív felmérő skálát nem alkalmaznak, nem vezetnek esésre vonatkozó statisztikát, továbbá protokoll sem található az intézményekben. Az esésmegelöző stratégia segítő és gátoló tényezői hat nagy területre rajzolódtak ki az interjúk során: lakók egészségi állapotának változása, személyzeti feltételek, biztonságos környezetet segítő intézeti infrastruktúra, ápolást segítő eszközök és tárgyi feltételek, továbbképzést és kommunikációt segítő stratégiák, a jogi szabályozás és protokollok megléte vagy hiánya. Az idősellátásban többnyire alacsony végzettségü ápolók/gondozók vesznek részt, ezért elengedhetetlenek látjuk az idősek ellátásában közremüködő ápolók ismereteinek és a gyakorlati készségeiknek a fejlesztését. Az interjúk során felfedeztünk számos jó gyakorlatot az esések megelőzéséért, szükségesnek látjuk azok megosztását egy közös platform segítségével. A minőségi vizsgálatunk messzemenő következtetéseket nem enged, ezért érdemesnek találjuk azt nagyobb elemszámú vizsgálatra kiterjeszteni.
\end{abstract}

ABSTRACT In nursing homes, preventing the fall of the elderly is a major challenge. In foreign literature, frequency of falls is estimated at $50-70 \%$. The aim of our research is to identify the number of nurses with health qualifications in nursing homes who are actively involved in the development and implementation of the fall prevention strategy, and to identify the factors that support or inhibit the strategy. Within the framework of our qualitative research, we conducted in-depth interviews incorporating semi-structured questions. Expert sampling was used to select the sample. Overall, 21 institutions in Csongrád county participated in the study. The interviews we conducted covered $26.5 \%$ percent of the staff of the institutions in the sample. Interviewed participants covered altogether $26.5 \%$ of the total sample of nursing homes in Csongrád county. On average, there is one caregiver with a medical degree for every 25.35 elderly residents in the nursing homes participating in the study. Frequency of falls is estimated at an average of $30 \%$ based on interviews and the occurrence of complications as a result of falling is at $10 \%$. An objective assessment of the risk of a fall is not used, no fall statistics are kept, nor there is a protocol in the institutions. The assisting and inhibiting factors of fall prevention strategy correspond to the following six major areas based on the conducted interviews: changes in the health of residents, staffing conditions, institutional infrastructure providing a safe environment, care support tools and material conditions, strategies to assist further training and communication, the existence or absence of legal regulation and protocols. Elderly care is provided mainly by low-skilled nurses/carers, so it is essential to improve the knowledge and practical skills of those involved in the care of the elderly. During interviews we discovered many best practices in nursing homes to prevent falls, we consider it necessary to share them using a common platform. Our qualitative study does not allow far-reaching conclusions, so we are considering to extend the study by conducting a larger number of interviews.

\section{KULCSSZAVAK esés,}

idősotthonok, prevenció, segítő és gátló tényezők

\section{SZERZŐI INFORMÁCIÓ}

Boros Edit ${ }^{1}$ és Dr. Balogh Zoltán ${ }^{2}$

${ }^{1}$ Semmelweis Egyetem

Doktori Iskola Budapest, Szegedi Tudományegyetem Egészségtudományi és Szociális Képzési Kar, Ápolási Tanszék, Szeged email: boros@etszk.u-szeged.hu

${ }^{2}$ Semmelweis Egyetem, Egészségtudományi Kar, Ápolástan Tanszék, Budapest 


\section{Bevezetés}

$\mathrm{Az}$ időskori elesésre népegészségügyi problémaként tekintünk, hiszen a hatvanas éveiben járó idősek egyharmadát, míg a 75 év feletti idősek felét érinti évente ez a nem várt esemény (WHO, 2015). Az idősek esése nem csak otthonukban, hanem egészségügyi intézményekben, ápolási otthonokban, idősek otthonában is jelen van. A Betegségmegelőzési és Járványügyi Központ (Centers for Disease Control and Prevention) felmérése szerint az akut osztályokon az esések gyakorisága 30\%-ra, míg az ápolási otthonokban és idősek otthonában 50-75\%-ra tehető. Az idősotthonokban az esések 12-20\%-a súlyos sérüléssel jár (Bergen, Stevens, \& Burns, 2016).

Az esések leggyakoribb oka idősek otthonában a járás és egyensúlyzavarok, gyengeség, szédülés, poszturális hipotenzió, kognitív és funkcionális károsodások, környezeti veszélyek mellett a látáskárosodás. Szintén jelentős kockázati tényező a többszörös gyógyszerhasználat, különös tekintettel a nyugtatókra és a pszichoaktív gyógyszerekre (Rubenstein és mtsai, 1994).

Az időskori esésmegelőző stratégia első lépése a veszélyeztetett személyek azonosítása, amelyet objektív felmérő skálák segítenek. Specifikusan idősotthonokban, lakóotthonokban alkalmazható esési kockázatfelmérő skálák is megtalálhatóak a nemzetközi szakirodalmakban.

A Downtow skála öt tételből áll, amely felméri az esés történetét, járásképességet, gyógyszerek alkalmazását és az alkoholfogyasztás mellett az érzékszervek károsodását és mentális státuszt (Rosendahl és mtsai., 2003). A FRAT (Falls Risk Assessment Tool- Esési Kockázat Felmérő Eszköz) pedig négy tételből áll, amelyben az esés történetét, a kognitív státuszt, pszichés állapotot és a gyógyszerek számát határozzák meg. Az utóbbi skála esetében, amennyiben az esés kockázata magas, az ápolók gondozási tervét egy csekklista segíti (MacAvoy és mtsai., 1996). Mindkét skála alkalmazása két percet vesz igénybe, tehát használatuk egyszerü, könnyen beilleszthető a mindennapi gyakorlatba.

A veszélyeztetett személyek meghatározása után szükség van intézményi esésmegelőző stratégia alkalmazására és egyéni szükségleteken alapuló ápolási tervre, amely segíti a biztonságos idősellátást.

A hatékony esésmegelőző beavatkozások idősotthonokban magában foglalják a környezet felmérését és módosítását (Connell, 1996), a gyógyszerek rendszeres felülvizsgálatát és szükség esetén a módosítását (Bor és mtsai., 2017), a vérnyomás ellenőrzését (Rubenstein, 2006), a járás és egyensúly fejlesztését torna segítségével (Sherrington és mtsai., 2019), valamint a helyes lábbeli és kényelmes ruházat biztosítása mellett (Kelsey és mtsai., 2010) a személyzet oktatását is (Vu, Weintraub, \& Rubenstein, 2006)(Vlaeyen és mtsai., 2015).

Hazánkban a NEVES (Nem Várt Események Fóruma) és a BELLA (Betegellátók Akkreditációja a biztonságos betegellátásért) programokban kiemelt helyet kapott az esésmegelőzés és a betegesések számának csökkentése. Számos jó gyakorlatot határoztak meg elsősorban egészségügyi ellátási környezetre, mint a betegesési szempontból kockázati csoportba tartozó személyek körének a meghatározását, kockázat felmérését, a különböző kockázatú betegek esetén alkalmazandó esésmegelőzési stratégiákat (Sinka, 2013)(Boros és mtsai., 2008).

Hazai szakirodalmakban az idősotthonokban élő idősek esési gyakoriságára, leggyakoribb esési szövődményekre, a gyakorlatban megvalósuló esésmegelőzési stratégiák és azokat segítő és gátló tényezőkre vonatkozó adatok szegényesnek mondhatóak. Nem ismerjük pontosan, hogy mennyi egészségügyi végezettségű ápoló vesz részt az idősek ellátásában, akik tevékenységet folytatnak az esésmegelőzésben. Jelen kutatásunk elsődleges céljai: 
- felmérni a Csongrád megyében tartós ápolást és gondozást nyújtó idősek otthonaiban, mennyi egészségügyi végzettséget szerzett ápoló vesz részt az ápolásban, akik érintettek lehetnek az esés kockázatának felmérésében, esés megelőzési tevékenység megszervezésében, komplex gondozási terv elkészítésében és kivitelezésében,

- felmérni, hogy milyen belső szabályozás vagy protokoll segíti a munkájukat az esés prevenció vonatkozásában,

- meghatározni, hogy milyen arányban fordul elő az időskori esés a mindennapi gyakorlatban, illetve milyen gyakran alakulnak ki esés következtében szövődmények,

- felmérni az esés prevencióját gátló és segítő tényezőket a munkájuk során.

A kutatás másodlagos célja meghatározni azokat az esésmegelőzési pontokat, amelyek javításra szorulnak, továbbá egy olyan továbbképzés fejlesztése, amely az idősotthonokban dolgozó ápolók és gondozók munkáját segíti.

\section{Kutatás módszere:}

Egyszeri keresztmetszeti vizsgálatunk 2019. december és 2020. február között folyt. A személyes és/vagy telefonos interjúk félstrukturált kérdések mentén történtek. Helyszíne a Csongrád megyében müködő idősek otthonai, amelynek listáját a Szociális portál nyílt hozzáférésű hivatalos intézménykereső rendszerén szürtük ki 2019. november 24-én. Az alkalmazott szürő „Szociális szolgáltatás / Személyes gondoskodás keretébe tartozó szakosított ellátások / Ápolást, gondozást nyújtó intézményi ellátás / Idősek otthona / Székhely megyéje: Csongrád megye", segítségével 18 intézményt, és azon belül összesen 25 tagintézményt találtunk. Ebből 14 önkormányzati, 7 központi kormányzati, 4 egyházi és 1 egyéb nem állami fenntartású intézmény, amelyekben összesen 2442 férőhelyet biztosítanak az idősek számára. A kutatás megkezdése előtt minden intézetvezetö/intézeti fenntartó engedélyét kértük, hogy feltárhassuk az idősek ellátásában dolgozó egészségügyi végzettséget szerzett ápolók létszámát, az intézetben előforduló esési statisztikákat, a leggyakoribb esési szövődményeket és esésmegelőzési protokoll tartalmát, továbbá, hogy milyen tényezők segítik vagy gátolják az esésprevenció megvalósulását. A kutatásban való részvételt 21 intézmény fogadta el. A szakértői mintavételt az engedélyt adott intézményvezető biztosította, megjelölve azt az ápolásvezetőt, vagy gondozásban részt vevő ápolót, akivel az interjút lefolytathattuk, így teljesültek a beválasztási kritériumok. Az egyik ilyen beválasztási kritérium, hogy az illető legalább 1 éves munkatapasztalattal rendelkezzen az adott munkahelyröl. Az a 21 személy, akikkel az interjút készítettük, a Csongrád megyei mintánk 26,5\%-át jelenti. A telefonos vagy személyes megkeresések 2019. december - 2020. február közötti időintervallumban történtek. A kutatáshoz kapcsolódó interjúk 20-40 percet vettek igénybe, az interjún elhangzott adatokat kézzel rögzítettük, amelyről az interjú alanyokat előzetesen tájékoztattuk és engedélyüket kértük.

\section{Eredmények:}

A 21 tagintézményben a megkeresett időpontban 1977 idős gondozása történt. Az intézményekben összesen 469 személyzet vett részt közvetlenül az idősek gondozásában, amelyből összesen 78 fö az, aki egészségügyi végzettséggel rendelkezett, így átlagosan 25,34 időskorú esik 1 egészségügyi végzettségű ápolóra (min.=7,2, max.=100). Az interjú során kiderült, hogy 21 intézetben nem található közvetlen esésmegelőzési protokoll, viszont 3 ápolóvezető jelezte, hogy rendelkeznek betegbiztonsági előírással, amelyben a biztonságos környezet kialakítása és az idősek mozgatásának szabályai vannak rögzítve.

$\mathrm{Az}$ intézetek nem vezetnek statisztikát arra vonatkozóan, hogy egy évben mennyi nem várt 
esemény következik be, de minden eseményt rögzítenek az eseménynaplóban vagy gondozási lapon, illetve a baleseti naplóban. A leírás, a dokumentáció tartalmazza a gondozott személy esésének időpontját, körülményeit és az esés következtében történt sérüléseket. Mivel éves statisztika nem készül az intézményekben, így az interjúban résztvevők az általuk tapasztalt esések gyakoriságát határozták meg. „Milyen gyakran fordult elő az Önök intézetében elesés az utóbbi egy évben?" kérdésre a válaszok az 1. sz ábrában láthatók. Az interjú alatt négy esetben derült arra fény, hogy a válaszoló az elesés számának meghatározása során nem gondolt arra, hogy az ágyból, vagy székből való leesés és lecsúszás is az esési kategóriába tartozik. Ezt követően korrigálta a válaszát az esés gyakoriságával kapcsolatban.

Ezután az elhangzott esetszámra számoltuk ki az éves esésszámot, majd arányosítottuk az intézetek összes lakójára. Az így kiszámolt esési gyakoriság a 21 intézetben 30\%-os volt (10-70\%). Az esések helyszínének leggyakrabban az ágyak közvetlen környezete mellett a fürdőszobát és/vagy a folyosót jelölték meg.
Az interjú kérdésekben kitértünk arra, hogy milyen esési szövődményekkel találkozott az ápoló az utóbbi egy évben az intézetben. A válaszokban a bőrsérülések (18 fö), végtagtörések (15 fö), csípőtáji törések (11 fö), fejsérülések (6 fö) jelentek meg, négy válasz alapján pedig nem történt szövődmény. Egy fö nem tudott nyilatkozni, mivel újonnan került az intézetbe, így még nem volt meg az egy éves tapasztalata. A szövődmények gyakoriságát is az intézetvezetők/gondozásban közremüködő ápolók beszámolói alapján határoztuk meg (1. sz ábra). A legnagyobb számban 2-3 havonta fordultak elö szövődmények ( 7 fö), majd ezt követte a félévente (4 fö), nem fordult elő szövődmény (4 fö), továbbá a havonta (2 fó), évente (2 fö), havi három esemény (1 fö).

Az idősek esési kockázatának felmérése a 21 intézetben a gondozó személyek megfigyelései és tapasztalatai alapján történik, standard esési kockázatfelmérő skála alkalmazásáról a megkérdezettek nem számoltak be.

Az interjú további kérdései arra irányultak, hogy a megkérdezettek foglalják össze, milyen tényezők segítik az esés megelőzését az intézményükben, és melyek azok, amelyek gátolják.

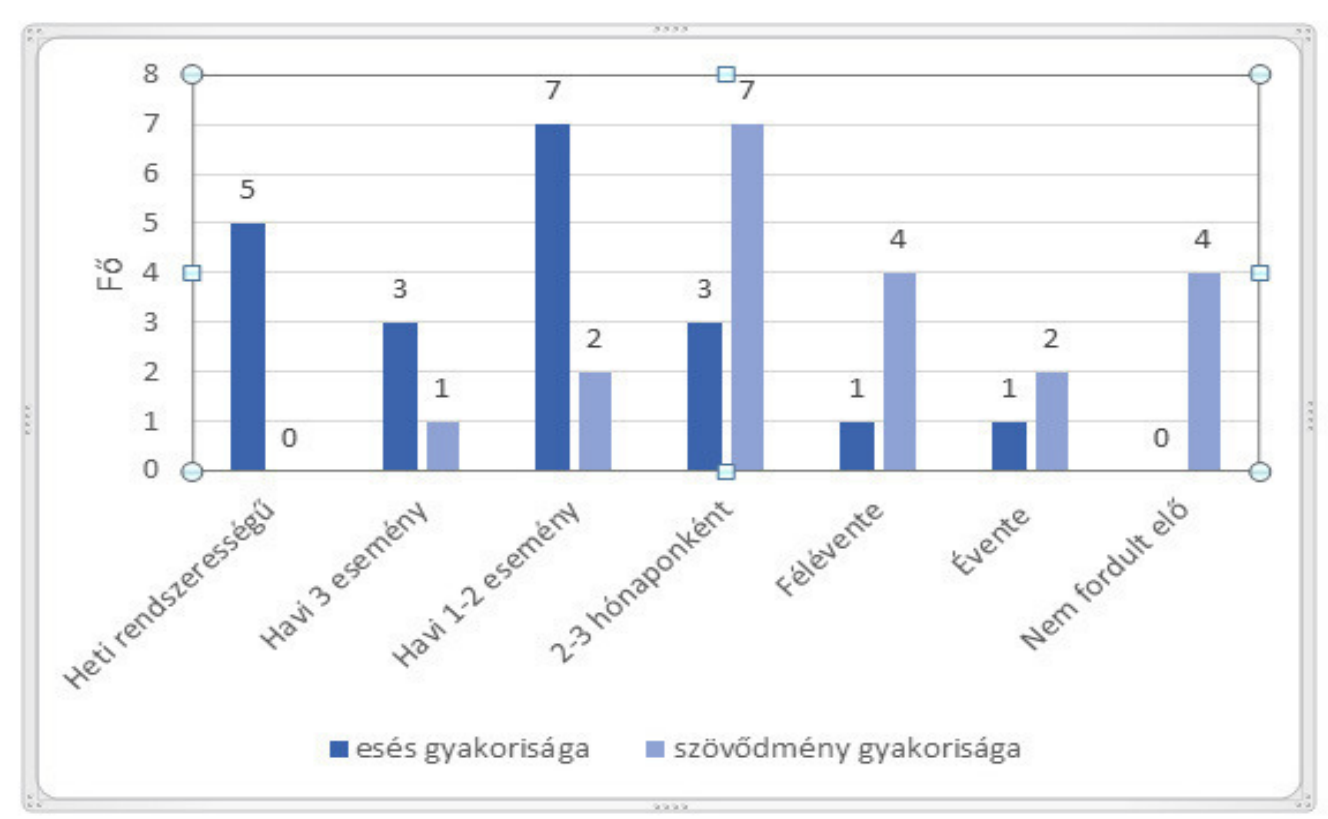

1.sz. ábra: Az esések és szövődményeinek gyakorisága a beszámolókban

$$
n=21
$$


Lakók egészségi állapota: Az interjúban résztvevők többsége kiemelte a lakók magas életkorát, az ezzel járó megromlott egészségi állapotukat és a megnövekedett gondozási igényt, mint gátló tényezőket ,egyre idősebbek a lakóink, több és komplexebb egészségi problémákkal... sok a demencia kórképpel rendelkezö lakónk is, akik gyakrabban elesnek." Az interjúkban elhangzott az is, hogy nagy kihívás a kognitív sérüléssel és a demencia kórképpel rendelkező idősek ellátása, különös tekintettel a biztonságuk megőrzése. Sokszor a lakóknak nincs teljeskörü kivizsgálása az intézetbe kerülés előtt, így ezt is pótolni kell a felvétel során „sok a dementálódott lakónk,... már a családtagok is elmondták, hogy otthonában is többször elesett, de kivizsgálva nem volt, hogy milyen problémák állnak a hátterében."

\section{Személyzeti erőforrások tekintetében} támogatóként jelenik meg minden intézetben a háziorvosi konzultáció, amely során a gyógyszerek áttekintése és állapotváltozások okának felderítésére van lehetőségük. 11 intézetben van jelen a gyógytornász, ebből legtöbb intézetben heti 2 alkalommal 2 órában tudja segíteni a lakók mobilizálását. 3 intézményben számoltak be arról, hogy egyéni gyógytornára is van lehetöség. Egyik beszámolóban elhangzott, hogy az izomerő és az egyensúly megtartása mellett a gyógytornász hangsúlyt fektet a helyes esési technika elsajátítására: „Gyógytornászunk a még jól mozgó időseket megtanitja arra szivacsmatracon, hogyan lehet úgy esni, hogy a fejüket ne üssék be, hogyan védjék magukat a súlyos sérülésektöl." Minden intézet részéről elhangzott az az igény, hogy szükség lenne magasabb óraszámban a gyógytornász jelenlétére. 9 intézetben nincs lehetőség gyógytornász foglalkoztatására, és ezt a problémát meg is nevezték az esésmegelőző stratégia gátjaként.

$\mathrm{Az}$ interjúkban részt vevők beszámoltak arról, hogy lehetőségük van rá és segítik is a munkájukat az ortopéd és reumatológus szakorvosok, valamint a gyógyászati segédeszköz forgalmazó munkatársak. Felmérik, hogy melyik lakónak milyen segédeszközre van szüksége a mobilitásuk megtartása és a biztonságos közlekedés érdekében.

A legnagyobb problémaként az interjúalanyok az elesés megelőzésében is az időskorúak és a gondozó személyzet/ápoló arányát jelölték meg. Minden intézmény a jogszabályi feltételeknek megfelelő gondozói létszámot biztosít, de a megváltozott gondozási igény miatt nem tartják elegendőnek. Az egy müszakban lévő gondozói személyzet létszámát néhány interjúban kritikusnak jelölték meg. Egyik interjúban elhangzott , ,éjszaka a két szintes épületben két gondozó van, nem tudnak mindenhol ott lenni... óvhatatlan, ha éjszaka zavart az idös akkor mindig ott tudjon lenni valaki, mielött az elindulna..., ekkor történik a legtöbb baj.” Másrészt kevésnek tartják az egészségügyi végzettségúek arányát, hiszen az egészségügyi végzettség garantálja a minőségi ellátási szintet. A probléma okaként a szociális és egészségügyi bértáblából adódó feszültséget jelölték meg: „, a múlt hónapban négy gondozó mondott fel, elmentek a kórházba dolgozni, mert segédápolói munkakörben jelentösen többet tud hazavinni, mint innen.” Másik interjúban: „mi biztositottuk, hogy az egészségügyi tanulmányát el tudja végezni..., majd megszerzés után a klinikára ment dolgozni..., több bér, egy müszakban kevesebb beteg volt az indok." A fizetés mellett a társadalmi elismerésben is látják a problémát: „a bér az egy probléma, amit lehetne orvosolni, de a társadalom megitélését nehezebb alakitani..., szükséges az elismerés, hogy itt maradjanak a dolgozók."

\section{Biztonságos környezet támogató} infrastruktúrát felmérő kérdéssel kapcsolatban változatos helyzetról számoltak be az interjúban résztvevők. 6 intézet számolt be arról, hogy azúj épület infrastruktúrája biztosítja azokat a lehetőségeket, amelyek támogatják a nem várt események, balesetek megelőzését. A tágas szobák és helyiségek nagymértékben csökkentik a zsúfoltság érzését, 
segítik az ápolási eszközök elhelyezését és a rend kialakítását a lakóotthonokban. A tágas közlekedési terület és a könnyen megközelíthető ágyak támogatják a biztonságosabb mozgatást és közlekedést a lakók számára. Az egyik interjúalany véleménye szerint, nem elegendő a modern infrastruktúra, szükséges az odafigyelés is, azaz mit lehet még fejleszteni: ,nálunk az intézetvezetö nagyon nyitott, nem elég az, hogy az épület modern és minden adott, mindig meghallgatja a tapasztalatainkat..., egyik alkalommal felfedeztük, hogy a lift egy kritikus pont az elesés szempontjából a még jól mozgó lakóknál. Az ajtó túl hamar záródott be és a sietés miatt történtek az esések. Jeleztük a megfigyelésünket és átállittattuk a záródási idöt. Azóta nem történt elesés a liftnél"

Négy interjúalany gátló tényezőként jelölte meg, hogy az épület öreg, ennek következtében más szempontok alapján épült, ami már a mai korszerü követelményeknek kevésbé felel meg. A tér szükös ahhoz, hogy az ápoláshoz szükséges eszközök is kényelmesen el tudjanak férni. Egyik interjúban az hangzott el: „szü̈kséges lenne a burkolat cseréje... annak idején még csúszásmentes padlózatnak számitott, de ez idôvel megkopott és elvesztette ezt a funkcióját." 4 interjúban az hangzott el, hogy probléma a nővérjelző rendszer hiánya vagy meghibásodása. ,Évek óta próbáljuk a jelzörendszert kialakitatni, de nincs rá megfelelö keretünk. Nagyban segítené a munkánkat..., ha egy lakónk el szeretne valahova indulni, felkelni az ágyból és segitségre lenne szüksége, tudna jelezni." Akadályként megemlítették az épületek belső szerkezetének hibái mellett a külső környezeti problémákat is. „Több épületben történik az ellátás, amely több szintü is..., a külső terület nagy, ami a látogatónak nagyon szép lehet, de számunkra probléma annak felügyelete. Itt több esés történik, mint magában az épületben."

Számos interjúban esésmegelőző stratégia gátjaként a lakószobákban lévő heverőket említették meg. A heverők magasságát nem lehet állítani, némelyik matraca nem egyenletes ezzel növelve a leesés kockázatát. Az idősek saját bútorzatukat használhatják az intézetben, ezzel segítve a beilleszkedést és az otthon elfogadását, de az nem mindig felel meg az ápolási szükségleteknek. Mások beszámolóiban elhangzott, hogy a modern betegágyak, amelyeknek magasságuk állítható, oldalán szükség esetén leesés gátló korláttal felszerelhető, nagy mértékben segíti a biztonságos idősellátást: „alapítványok segítettek minket a modern ágyak beszerzésében, így fokozatosan le tudtuk cserélni a heveröket a magasabb ápolási igényü lakóknál."

Az ápolást segítő eszközök megléte vagy hiánya több interjú során megjelent. A betegek transzportját segítő eszközöket emelték ki, az idősek egyéni szükségletein alapuló járást segítő eszközök elengedhetetlenek a biztonságos mozgás megtartásában. Az intézetek ilyen problémába nem ütköznek, minden idős számára az alkalmas segédeszközt tudják biztosítani. Viszont a betegek mozgatását segítő eszközök vonatkozásában már változatos képet találunk. Öt interjúalany számolt be arról, hogy csúsztató lepedő, csúsztató lapok, betegemelők segítik az ágyban való pozícióváltást, vagy ágyból való kihelyezést. Az egyik interjúban a segédeszközök alkalmazására vonatkozó szemlélet fontosságát emelte ki a válaszoló: „,Minden modern eszközt beszereztem a biztonságos mozgatáshoz, hogy segitsem a gondozókat..., pár nap múlva a raktárban találtam, mert nem szerették használni..., majd tartottunk egy-két továbbképzést és rendszeresen elövettük az eszközöket, igy lassan belátták az eszközök hasznát." Hét ápoló beszámolójában jelent meg a fürdető ágy jelentősége az esés megelőzésében, amely segíti az időskorúak higiénés szükségletének támogatását balesetmentes környezetet biztosítva.

$\mathrm{Az}$ intézményben folyó továbbképzések, gondozói értekezletek, mint esésmegelőző stratégiák 8 interjúban hangzottak el. Fontosnak gondolják a szakmai megbeszéléseket és továbbképzéseket. A témakörök, amelyek megjelentek a beszámolókban 
a biztonságos betegmozgatás, környezet szerepe a biztonságban, elsősegélynyújtás alapjai sérülések esetén. A szakmai megbeszélések tartalmaként megjelölték az esés körülményeinek az elemzését, megelőzésének lehetőségeit. Az interjúkban résztvevők többsége megjegyezte, hogy szeretnének többet tudni az esésmegelőző stratégiákról és lehetséges gyakorlati módszerekről továbbképzések keretében.

\section{Megbeszélés és vita}

Egyszeri keresztmetszeti vizsgálatunk elsődleges célja volt, hogy feltárjuk a Csongrád megyei idősotthonokban előforduló esési gyakoriságot, meghatározzuk, hogy az adott intézményben található-e esésmegelőző protokoll, amely az ápolók munkáját segíti. Eredményeink alapján jól látszik, hogy az intézményekben jelentős probléma az előforduló esések és azok szövődményei.

$\mathrm{Az}$ intézmények nem regisztrálják az esések éves gyakoriságát, nem történik célzottan az esések kockázatának felmérése. A felmérésünkben számolt esési gyakoriságot csak tájékoztató jellegünek tekinthetjük, mivel az interjún résztvevők tapasztalataira tudtunk egy arányszámot kalkulálni, ezért szükségesnek tartjuk az esési statisztika feltérképezését az idősek ellátásában egy objektív felmérő és jelentési rendszer segítségével. Habár az idősotthonokban alkalmazható esés kockázatát felmérő skálák már számos országban rendelkezésre állnak, hazánkban még nem alkalmazzák azokat. A betegbiztonsági programok megkövetelik, hogy a kockázatokra fókuszáljuk és azokat mielőbb megszüntessük, ezzel is biztosítva a prevenciós szemléletet. A kérdőívek használata az esések számát közvetlenül ugyan nem csökkenti, de alkalmazásukkal az ellátás irányítását, személyközpontúságát támogatják. $\mathrm{Az}$ intézetek esésmegelözési protokollal nem rendelkeznek, 3 intézmény beszámolt arról, hogy az ellátottak mozgatásához és a biztonságos környezet kialakításához belső szabályzat segíti a munkájukat. Ezen adatok azt mutatják, hogy szükséges az esésmegelőzését támogató protokollok kialakítása az idősotthonokban, amely nem csak a dolgozók munkáját támogatja, de minőségbiztosítási és

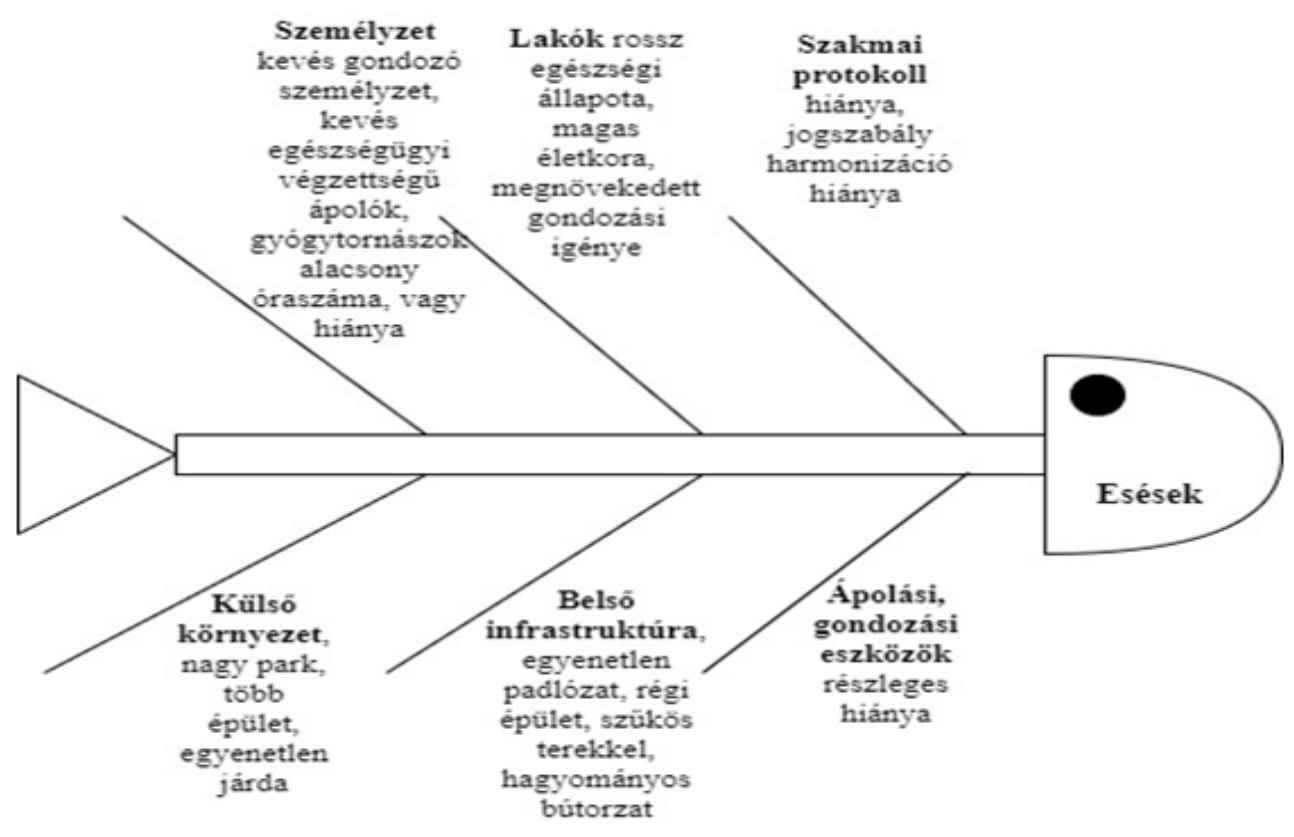

2. sz. ábra: Az esésmegelözési stratégia ok-hatás diagramja az idősotthonokban 
betegbiztonsági szempont alapján is elengedhetetlen.

Az elesés megelőzést segítő és gátló faktoroknak az interjú során az alábbi területek rajzolódtak ki: lakók egészségi állapotának változása, személyzeti feltételek, biztonságos környezetet támogató intézeti infrastruktúra, ápolást segítő eszközök és tárgyi feltételek, továbbképzést és kommunikációt segítő stratégiák és a jogi szabályozás és protokollok (2. sz. ábra).

Minden megjelölt területen több megoldandó feladatot találtak, de legsürgetőbbnek a jogi harmonizációt jelölték meg. A személyi feltételeket az idősotthonokban a $1 / 2000$ (I. 7.) SZCSM rendelet határozta meg, majd 36/2007 SZMM rendeletben változott az ellátottak gondozási szükségletének meghatározása, illetve hogy milyen feltételek esetén vehető igénybe az ellátás. A rendelet értelmében 2007 óta magasabb gondozási igényü ellátottak kerülnek intézeti felvételre, emellett jellemző a magas életkor és multimorbiditással rendelkező lakók jelenléte, ennek ellenére ajogi szabályozás nem követte és nem korrigálta a személyzeti feltételeket. Az interjú alanyai nem tekintik optimálisnak az idősek ellátásában résztvevő személyek arányát a megváltozott feltételekhez.

Kutatásunk eredményei összhangban vannak a Norvégiában és az Amerikai Egyesült Államokban végzett felméréssel, miszerint az idősotthonokban az alacsony bérek, a gondozói presztízs hiánya együttesen nehezíti az ápolói szakemberek bevonzását és megtartását az intézményekben. A személyzethiány a minőségjavítás legszembetűnőbb akadálya (Clancy és Mahler, 2016) (Gruneirs és Mor, 2008).

Az interjú alatt pontosítani kellett az esések kategóriájába tartozó váratlan események formáit. $\mathrm{Az}$ interjúkban résztvevők szükségesnek látják az esésmegelőzésről szóló ismeretek fejlesztését továbbképzéseken és szakmai beszélgetések alkalmával. Ez a vélemény és igény összhangban van a NEVES fórum által közvetített üzenettel, miszerint szükséges a dolgozók ismeretét növelni a potenciális veszélyforrásokról és esésmegelőzési stratégiákról (Sinka, 2013). A vizsgálatban résztvevők fontosnak tartják azoknak a jó gyakorlatoknak a megosztását, amelyek nagy erőforrás befektetést nem igényelnek, de segítik a személyre szóló, biztonságos idősellátást. Leverenz és munkatársa kutatása alapján 4 órás továbbképzés már hatékony a gondozó személyzet ismereteinek és készségeinek fejlesztésén túl a megszerzett ismeretek magabiztos gyakorlatban való alkalmazására (Leverenz \& Lape, 2018).

Szükségesnek látjuk magasabb elemszámú vizsgálat elvégzését, amely az ápolók esés fogalmának ismeretén túl a kockázati tényezők és lehetséges esésmegelőző beavatkozások ismeretének és azok gyakorlati alkalmazásának felmérését is tartalmazza, hogy helyi problémáknak megfelelő esésmegelőző továbbképzést tudjuk kialakítani, amely támogatja az ápolók munkáját.

\section{Etikai jóváhagyás:}

A tanulmány összhangban áll a Helsinki Nyilatkozat elveivel.

\section{Összeférhetetlenség:}

A szerzők kijelentik, hogy nincs összeférhetetlenség. Ez a tanulmány „Az elesés megelőzésének lehetőségei időskorúak körében" kutatás részét képezi, a projekt az Európai Unió támogatásával, az Európai Szociális Alap társfinanszírozásával valósul meg. EFOP-3.6.1-162016-00008, melynek résztvevője $B E$.

\section{Irodalomjegyzék}

1/2000. (I. 7.) SzCsM rendelet a személyes gondoskodást nyújtó szociális intézmények szakmai feladatairól. Letöltés dátuma:2020.01.22 Elérhető: https://net.jogtar.hu/jogszabaly?docid=a0000001. $\mathrm{scm}$

36/2007. (XII. 22.) SZMM rendelet a gondozási szükséglet, valamint az egészségi állapoton alapuló szociális rászorultság vizsgálatának és igazolásának részletes szabályairól. Letöltés dátuma:2020.01.22. Elérhető: 
https://net.jogtar.hu/jogszabaly?docid=a0700036. $\mathrm{smm}$

Bergen, G., Stevens, M. R., \& Burns, E. R. (2016). Falls and Fall Injuries Among Adults Aged $\geq 65$ Years - United States, 2014. MMWR. Morbidity and Mortality Weekly Report. https://doi.org/10.15585/ mmwr.mm6537a2

Bor, A., Matuz, M., Csatordai, M., Szalai, G., Balint A, Benkő, R., ... Doró, P. (2017). Medication use and risk of falls among nursing home residents: a retrospective cohort study https://doi.org/10.1007/ s11096-017-0426-6

Boros, E., Öry, C., Udvardiné, H. S., \& Tihanyi, M. (2008). Nemkívánatos esemény 3 - A betegek elesése és leesése. Kórház, 3, 41-44. Elérhető: https://weborvos.hu/adat/korhaz/2008marc/41-44. pdf

Clancy, A., \& Mahler, M. (2016). Nursing staffs' attentiveness to older adults falling in residential care - an interview study. Journal of Clinical Nursing. https://doi.org/10.1111/jocn.13240

Connell, B. R. (1996). Role of the environment in falls prevention. Clinics in Geriatric Medicine. https://doi.org/10.1016/s0749-0690(18)30205-2

Gruneir, A., \& Mor, V. (2008). Nursing Home Safety: Current Issues and Barriers to Improvement. Annual Review of Public Health. https://doi. org/10.1146/annurev.publhealth.29.020907.090912

Kelsey, J. L., Procter-Gray, E., Nguyenb, U. S. D. T., Li, W., Kiel, D. P., \& Hannan, M. T. (2010). Footwear and falls in the home among older individuals in the MOBILIZE Boston study. Footwear Science, Sep 2(3), 123-129. https://doi. org/10.1080/19424280.2010.491074

Leverenz, M., \& Lape, J. (2018). Education on Fall Prevention to Improve Self-Efficacy of Nursing Staff in Long Term Care: a Pilot Study. The Internet Journal of Allied Health Sciences and Pravtice, Jul 02. 16(3), Article 6. Elérés: https://nsuworks.nova. edu/ijahsp/vol16/iss3/6/

MacAvoy, S., Skinner, T., \& Hines, M. (1996). Fall risk assessment tool. Applied Nursing Research, 9(4), 213-218. https://doi.org/10.1016/S08971897(96)80127-3
Rosendahl, E., Lundin-Olsson, L., Kallin, K., Jensen, J., Gustafson, Y., \& Nyberg, L. (2003). Prediction of falls among older people in residential care facilities by the Downton index. Aging Clinical and Experimental Research. https://doi.org/10.1007/ BF03324492

Rubenstein, L. Z. (2006). Falls in older people: epidemiology, risk factors and strategies for prevention. Age Ageing. https://doi.org/10.1093/ ageing/afl084

Rubenstein, L. Z., Josephson, K. R., \& Robbins, A. S. (1994). Falls in the nursing home. Annals of Internal Medicine. https://doi.org/10.7326/00034819-121-6-199409150-00009

Sherrington, C., Fairhall, N. J., Wallbank, G. K., Tiedemann, A., Michaleff, Z. A., Howard, K., ... Lamb, S. E. (2019). Exercise for preventing falls in older people living in the community. The Cochrane Database of Systematic Reviews, 1(1), CD012424CD012424. https://doi.org/10.1002/14651858. CD012424.pub2

Sinka, E. (2013). Betegesés megelözése. In NEVES Fórum. Budapest: Semmelweis Egyetem Egészségügyi Menedzserképző Központ. Elérés forrás https://info.nevesforum.hu/wp-content/ uploads/2016/01/Betegesés-standard_20131205_ SE.pdf

Vlaeyen, E., Coussement, J., Leysens, G., Van Der Elst, E., Delbaere, K., Cambier, D., ... Milisen, K. (2015). Characteristics and effectiveness of fall prevention programs in nursing homes: A systematic review and meta-analysis of randomized controlled trials. Journal of the American Geriatrics Society. https://doi.org/10.1111/jgs.13254

Vu, M., Weintraub, N., \& Rubenstein, L. (2006). Falls in the Nursing Home: Are They Preventable? Journal of the American Medical Directors Association, 7, 52, S53-8. https://doi.org/10.1016/j. jamda.2005.12.016

World Health Organisation (WHO). (2015). WHO | Falls Prevention in Older Age. Elérés 2017. június 27., Forrás: http://www.who.int/ageing/projects/ falls_prevention_older_age/en/\#.WVJp0HN2Khg. mendeley 